\title{
Biosorption of $\mathbf{P b}$ (II) from aqueous solutions by modified of two kinds of marine algae, Sargassum glaucescens and Gracilaria corticata
}

\author{
Akbar Esmaeili", Mona Kalantari, Betsabe Saremnia \\ Islamic Azad University, Department of Chemical Engineering, North Tehran Branch, Tehran, Iran. \\ "Corresponding author: e-mail: akbaresmaeili@iau.ac.ir
}

\begin{abstract}
In this research, the batch removal of $\mathrm{Pb}^{2+}$ ions from wastewater and aqueous solution with the use $\mathrm{o}$ two different modified algae Gracilaria corticata (red algae) and Sargassum glaucescens (brown algae) was examined. The experiment was performed in a batch system and the effect of the $\mathrm{pH}$ solution; initial concentration and contact time on biosorption by both biomasses were investigated and compared. When we used S. glaucescens as a biosorbent, the optima conditions of $\mathrm{pH}, \mathrm{Pb}^{2+}$ concentration and equilibrium time were at $5,200 \mathrm{mg} / \mathrm{L}$ and $70 \mathrm{~min}$, in the range of $95.6 \%$ removal. When $G$. corticata was used for this

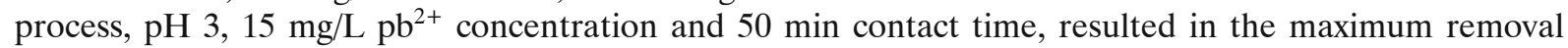
(86.4\%). The equilibrium adsorption data are fitted to the Frundlich and Langmuir isotherm model, by $S$. glaucescens and $G$. corticata, respectively. The $\mathrm{pb}^{2+}$ uptake by both biosorbent was best described by the second-order rate model.
\end{abstract}

Keywords: Biosorption. Lead (II), Removal, Gracilaria corticata, Sargassum glaucescens, Isotherm mode.

\section{INTRODUCTION}

Protection of the environment is a major concern of human communities. Development and various related activities release lots of poisonous materials into the environment and heavy metals are the most dangerous of all ${ }^{1}$. Biosorption is a proven technology for the removal of heavy metal ions from synthetic and real industrial effluents. Several researchers investigated numerous biomass types and proposed excellent metal biosorbents including bacteria, fungi, seaweed. Among the most promising biomaterials studied, seaweed was found to be very efficient and binds variety of metals ${ }^{2}$. The biosorption capability of algae has been attributed mainly to the cell wall. Some successfully used and best performed seaweed for cobalt and nickel biosorption include Ascophyllum nodosum for cobalt removal and Sargassum fluitans for nickel removal. Modeling of biosorption isotherm data is important for predicting and comparing biosorption performance. The two widely accepted for single solute systems are the Langmuir and Freundlich isotherms ${ }^{3}$. The discharge of metal ions in industrial effluents is of great concern because their presence and accumulation can have toxic or carcinogenic effects on living species. At least 20 metals are classified as toxic, and half of these are emitted into the environment in quantities that show risk factors to human health ${ }^{4}$. Heavy metals are major pollutants that have caused significant environmental problems. Various physical and chemical methods are used for treating heavy metals from industrial wastewater, that include: adsorption, ion exchange, complication, chelating, membrane separation ${ }^{5,6}$. Different biomass types such as bacteria, fungi and algae have been used to treat wastewater. Biosorption is a term that describes the removal of heavy metals by the passive binding to nonliving microorganisms from an aqueous solution ${ }^{7,8}$. Marine algae are biological resources which are available in the world. The use of algae, the batch removal of nickel (II) ions from aqueous solution under different experimental conditions using the activated carbon prepared of red alga Gracilaria $^{9}$, biosorption of copper from wastewater by the activated carbon preparation from alga Sargassum sp. ${ }^{10}$, the batch removal of toxic hexavalent chromium ions from wastewater and aqueous solution using two different activated carbon marine algae Gracilaria (red algae) and Sargassum sp. (brown algae) were examined. Activated carbon prepared from Gracilaria and Sargassum sp. ${ }^{11}$. The use of algae, Durvillae pototatorum, Ecklonia radiate ${ }^{12}$ Ascophyllum nodosum ${ }^{2}$ and Saccharomyces crevisiae ${ }^{13}$, Spirogyra ${ }^{14}$ for heavy metal removal has been reported. In this research, the batch removal of $\mathrm{Pb}^{2+}$ ions from wastewater and aqueous solution using by modified two different algae $G$. corticata (red algae) and Sargassum glaucescens (brown algae) were examined. The effect of contact time, initial concentration, and $\mathrm{pH}$ and equilibrium isotherms on the process was studied.

\section{EXPERIMENTAL}

\section{Preparation of biomass}

Gracilaria corticata (red algae) and Sargassum glaucescens (brown algae) were collected from the Persian Gulf on Queshm Island. Before use, these were washed several times with tap water to remove the sand particles and salts. They were then sun dried for 6 days. The dry biomass was chopped, milled (size fraction of $0.5-1 \mathrm{~mm}$ ) and then used for biosorption experiments ${ }^{25}$.

\section{Preparation of $\mathbf{P b}^{2+}$ solution}

Stock $\mathrm{Pb}^{2+}$ solution $(800 \mathrm{mg} / \mathrm{L})$ was prepared by dissolving $0.37 \mathrm{~g}$ of $\mathrm{pb}\left(\mathrm{CH}_{3} \mathrm{COO}\right)_{2} \cdot 3 \mathrm{H}_{2} \mathrm{O}$ (Merck) in 250 $\mathrm{mL}$ of deionized water. Different concentrations of $\mathrm{Pb}^{2+}$ solution were prepared by the dilution of deionized water. The initial $\mathrm{pH}$ of sample solution was adjusted with $1 \mathrm{M} \mathrm{HCl} / 1 \mathrm{M} \mathrm{NaOH}$ using digital $\mathrm{pH}$ meter. All the adsorption experiments were carried out at room temperature $\left(23 \pm 2{ }^{\circ} \mathrm{C}\right)^{11}$.

\section{Preparation of Biomass}

Red marine macroalgae G. corticata and brown algae $S$. glaucescens were used for the removal of $\mathrm{pb}^{2+}$ from aqueous solution. They were collected from the Persian 
Gulf on Queshm Island, Iran and washed several times with tap water to remove the sand particles and dirt. Then dried for 5 days. The dry biomass was grounded to particle size.

\section{Determination of the $\mathrm{Pb}^{2+}$ contents}

Concentration of $\mathrm{Pb}^{2+}$ in the solution before and after the equilibrium was determined using a Perkin Elmer Analyst 300 atomic absorption spectrometer equipped with a deuterium lamp as the background corrector and an air-acetylene burner, and controlled by an IBM personal computer. The hollow cathode lamp was operated at $15 \mathrm{~mA}$, and the analytical wavelength was set at $324.8 \mathrm{~nm}$.

\section{Adsorption experiments}

A series of flasks containing $\mathrm{Pb}^{2+}$ solutions varying in the concentration from 10-30 ppm of biomass for $G$. corticata and 50-250 ppm of biomass for S. glaucescens were prepared from the stock solution. Adjustment of $\mathrm{pH}$ was carried out using $1 \mathrm{~N} \mathrm{NaOH}$ and $1 \mathrm{~N} \mathrm{H}_{2} \mathrm{SO}_{4}$. Batch equilibrium sorption experiments were carried out in Erlenmeyer flasks for G. corticata and S. glaucescens were 90 (10-30 ppm of biomass of metal solution) and 70 min (50-250 ppm of biomass, of metal solution) respectively, in a rotary shaker. These experiments were done at $\mathrm{pH}$ 1.0-13.0. After the sorption equilibrium was reached (90 and $70 \mathrm{~min}$ ), the solution was separated from the biomass by membrane filtration. The initial and equilibrium $\mathrm{Pb}^{2+}$ concentrations in each flask were determined by atomic absorption spectrometry (AAS). To maximize $\mathrm{Pb}^{2+}$ removal by the adsorbent, batch experiments were conducted at a constant temperature using the optimum conditions of all pertinent factors, such as dose, $\mathrm{pH}$, initial concentration, and contact time. Subsequent adsorption experiments were carried out using only the optimized parameters.

\section{Equilibrium isotherm}

\section{Lead uptake capacities and sorption isotherm}

The amount of metal adsorbed by activated carbon was calculated from the difference between the metal quantity added to the biomass and the metal content of the supernatant using the equation

$\mathrm{q}_{e}=\left(\mathrm{C}_{0}-\mathrm{C}_{e}\right) \mathrm{V} / \mathrm{M}$

where $q_{e}$ is the metal uptake (mg metal adsorbed per $\mathrm{g}$ adsorbent), $\mathrm{C}_{0}$ and $\mathrm{C}_{e}$ are the initial and equilibrium metal concentrations in solution $(\mathrm{mg} / \mathrm{L}), \mathrm{V}$ is the volume of the solution $(\mathrm{mL})$, and $\mathrm{M}$ is the weight of algae marine (g). To examine the adsorbed and aqueous concentration at equilibrium, sorption isotherm models and Langmuir and Freundlich adsorption models were used for the data. These isotherm constants for $\mathrm{Pb}^{2+}$ are presented in Table 1.

\section{Freundlich adsorption model}

The Freundlich model ${ }^{15}$ habitually gives a better fit for adsorption from liquids and can be expressed as $\mathrm{q}_{e}=\mathrm{K}_{f} \mathrm{C}_{e}^{1 / n}$

In this model, the rate of adsorption is of the constants $1 / \mathrm{n}$ and $\mathrm{K}_{\mathrm{f}}(\mathrm{L} / \mathrm{g})$. For a good adsorbent, $0.2<1 / \mathrm{n}<0.8$,
Table 1. The isotherm parameters obtained for the biosorption of $\mathrm{Pb}^{2+}$

\begin{tabular}{|l|c|c|}
\hline Isotherm model & S. glaucescens & G. corticata \\
\hline Langmuir & & \\
\hline $\mathrm{Q}_{\mathrm{m}}(\mathrm{mg} / \mathrm{g})$ & -6.56 & 0.761 \\
\hline $\mathrm{b}(\mathrm{L} / \mathrm{mg})$ & -0.0479 & 5.43 \\
\hline $\mathrm{R}^{2}$ & 0.487 & 0.999 \\
\hline Freundlich & & \\
\hline $1 / \mathrm{n}$ & 1.587 & 0.1535 \\
\hline $\mathrm{K}_{\mathrm{f}}(\mathrm{mg} / \mathrm{g})(\mathrm{L} / \mathrm{mg})^{1 / \mathrm{n}}$ & 0.163 & 0.569 \\
\hline $\mathrm{R}^{2}$ & 0.883 & 0.6294 \\
\hline
\end{tabular}

and a smaller value of $1 / \mathrm{n}$ shows better adsorption and formation of a rather strong bond between the adsorbate and the adsorbent. Many researchers have used this model to interpret this sorption data for various systems ${ }^{\mathbf{1 6}-19}$.

\section{Langmuir adsorption model}

The most widely used isotherm equation for modeling equilibrium is the Langmuir equation. It is assumed that there is a finite number of binding sites that are homogeneously shared over the adsorbent surface. These binding sites have the same adsorption of a single molecular layer, and there is no interaction between adsorbed molecules. The saturated monolayer isotherm can be represented as

$\mathrm{q}_{e}=\mathrm{bq}_{\max } \mathrm{C}_{e} /\left(1+\mathrm{bC}_{e}\right)$

where $\mathrm{q}_{e}$ is metal ions adsorbed $(\mathrm{mg} / \mathrm{g}), \mathrm{C}_{e}$ is the equilibrium concentration $(\mathrm{mg} / \mathrm{L}), \mathrm{q}_{\max }$ is the maximum adsorption capacity, and $\mathrm{b}$ is an affinity constant; $\mathrm{q}_{\max }$ epresents a practical limiting adsorption capacity when the surface is fully covered with metal ions and assists in the comparison of adsorption performance, in the cases where the sorbent did not reach its full saturation in experiments and $\mathrm{b}$ is constantly related to the affinity of the binding sites ${ }^{20}$.

\section{Adsorption kinetic studies}

The kinetics of adsorption describes the rate of lead ion uptake on the prepared from G. corticata and $S$. glaucescens, which controls the equilibrium time. These kinetic models included the first-order and second-order equations.

\section{Pseudo first-order model}

The pseudo first-order rate expression is described by the equation

$\mathrm{dq}_{t} / \mathrm{d}_{t}=\mathrm{k}_{1}\left(\mathrm{q}_{e}-\mathrm{q}_{t}\right)$

where $\mathrm{q}_{e}$ is lead adsorbed at equilibrium per unit weight of the sorbent $(\mathrm{mg} / \mathrm{g}), \mathrm{q}_{t}$ is copper adsorbed $(\mathrm{mg} / \mathrm{g})$, and $\mathrm{k}_{\mathrm{l}}$ is the rate constant $\left(\mathrm{min}^{-1}\right)^{\mathbf{2 0}}$. The integrated form of Eq. (4) becomes

$\log \left(\mathrm{q}_{\mathrm{e}}-\mathrm{q}_{\mathrm{t}}\right)=\log \left(\mathrm{q}_{\mathrm{e}}\right)-\left(\mathrm{k}_{1 / 2.303}\right) \mathrm{t}$

A plot of $\log \left(\mathrm{q}_{e}-\mathrm{q}_{t}\right)$ versus $(\mathrm{t})$ indicates a straight line of slope $\left(\mathrm{k}_{1 / 2.303}\right)$ and an intercept of $\log \left(\mathrm{q}_{e}\right)$.

\section{Pseudo second-order model}

The sorption data also analyzed a pseudo second order (Ag and Aktay 2002), given by:

$\mathrm{dq}_{\mathrm{t}} / \mathrm{d}_{\mathrm{t}}=\mathrm{K}_{2}\left(\mathrm{q}_{\mathrm{e}}-\mathrm{q}_{\mathrm{t}}\right)^{2}$ 
where $K_{2}$ is the equilibrium rate constant ( $\left.\mathrm{g} / \mathrm{mg}, \mathrm{min}\right)$, and $\mathrm{q}_{e}$ and $\mathrm{q}_{t}$ are the sorption capacities at equilibrium at time $t$. The integrated form of Eq. (5) becomes

$1 /\left(\mathrm{q}_{\mathrm{e}}-\mathrm{q}_{\mathrm{t}}\right)=1 /\left(\mathrm{q}_{\mathrm{e}}\right)+\mathrm{K}_{2} \mathrm{t}$

which has a linear form:

$\mathrm{t} / \mathrm{q}_{\mathrm{t}}=1 / \mathrm{K}_{2} \mathrm{q}_{e}^{2}+\left(1 / \mathrm{q}_{\mathrm{e}}\right) \mathrm{t}$

A plot $\mathrm{t} / \mathrm{q}_{t}$ versus $t$ shows a straight line of slope $\left(1 / \mathrm{q}_{e}\right)$ and an intercept of $\left(1 / \mathrm{K}_{2} \mathrm{q}_{e}^{2}\right)^{21}$.

In this study, the batch method was used for the biosorption of lead by $G$. corticata and $S$. glaucescens.

\section{Statistical Analysis}

Error bars are indicated wherever necessary. All statistical analysis was done using SPSS12 for windows. The statistical significance of differences among the values was assessed by using the one-way ANOVA test.

\section{RESULTS AND DISCUSSION}

The present study shows biosorption of $\mathrm{Pb}^{2+}$ ions by two kinds of modified marine algae $G$. corticata (red algae) and $S$. glaucescens (brown algae) biomass from aqueous solutions was investigated. The data obtained from this work supports the view that the $S$. glaucescens is an effective and low-cost adsorbent for the removal of $\mathrm{Pb}^{2+}$ from aqueous solutions. The adsorption of metal ions is dependent on $S$. glaucescens, concentration of metal ions, retention time, and $\mathrm{pH}$ of the metal solution.

\section{Effect of contact time}

To find the suitable equilibrium time of the biosorption, an experiment was carried out at different time intervals

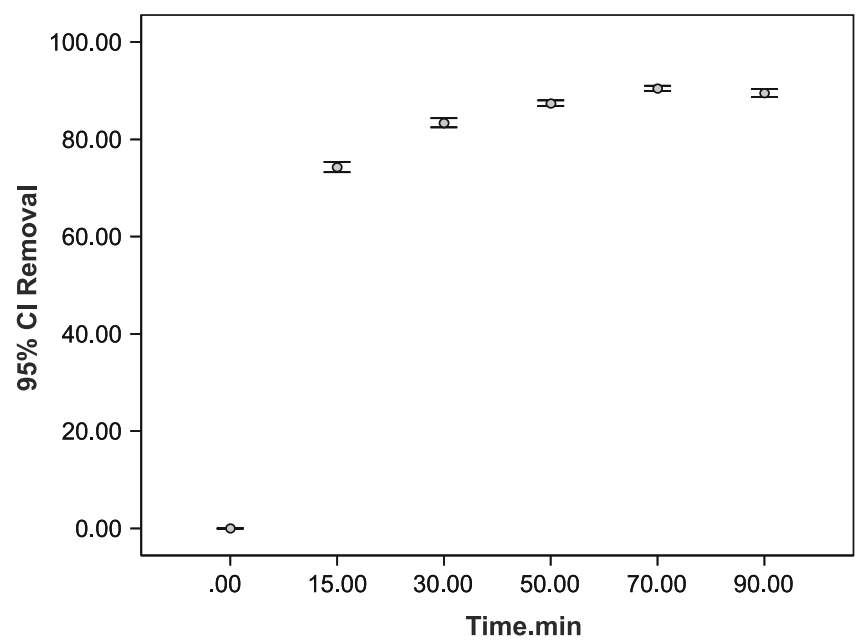

Figure 1a. Biosorption of $100 \mathrm{ml} \mathrm{Pb}^{2+}$ solution, 100 and $25 \mathrm{mg} / \mathrm{L}$, by Sargassum glaucescens $200 \mathrm{rpm}$ shaking rate in different times
$(15,30,50,70$ and $90 \mathrm{~min})$. As it can be seen in figure 1 with the beginning of the process, the uptake of $\mathrm{pb}$ ions increased quickly and after 70 and $50 \mathrm{~min}$ for the 100 and $25 \mathrm{mg} / \mathrm{L}$ of $\mathrm{pb}^{2+}$ solution, the exchange ion became slow, by $S$. glaucescens and $G$. corticata, respectively. It seems that, $S$. glaucescens is more effective in the removal of high concentration of lead solution.

Optimum contact time for both the dried and activated carbon biosorbent was found to be $120 \mathrm{~min}$. In previous literature, similar findings have been reported by the evaluation of the marine alga $G$. corticata for the adsorption of $\mathrm{Cu}$ (II) from wastewater in a packed column ${ }^{22}$.

\section{Effect of initial concentration}

The initial concentration of metal ions provides an important driving force to overcome all mass transfer resistances of metal ions between the aqueous and solid phases ${ }^{9}$. The influence of metal ion concentration on the biosorption by $S$. glaucescens and $G$. corticata has been shown in figure $2 \mathrm{a}$ and figure $2 \mathrm{~b}$ respectively.

As it can be seen, by increasing the initial concentration, the removal percent was increased by using $S$. glaucescens and the maximum removal of $\mathrm{pb}^{2+}$ ions, after $70 \mathrm{~min}$ was $200 \mathrm{mg} / \mathrm{L}$ in the range of $89.11 \%$. As shown in figure $2 \mathrm{~b}$, the removal of $\mathrm{pb}^{2+}$ ions by $G$. corticata was decreased, by increasing metal concentration and the maximum removal after 50 min was $15 \mathrm{mg} / \mathrm{L}$ in the range of $99.2 \%$. Thus $S$. glaucescens is useful for the removal of high concentrations of $\mathrm{pb}^{2+}$. In recent studies, biosorption of $\mathrm{Ni}$ (II) with 30,50 and $70 \mathrm{mg} / \mathrm{L}$, by $\mathrm{G}$. corticata, after $60 \mathrm{~min}$ was in the ranges of 99.03 , 97.99 and $95.12 \%{ }^{9}$. And G. corticata was used for the

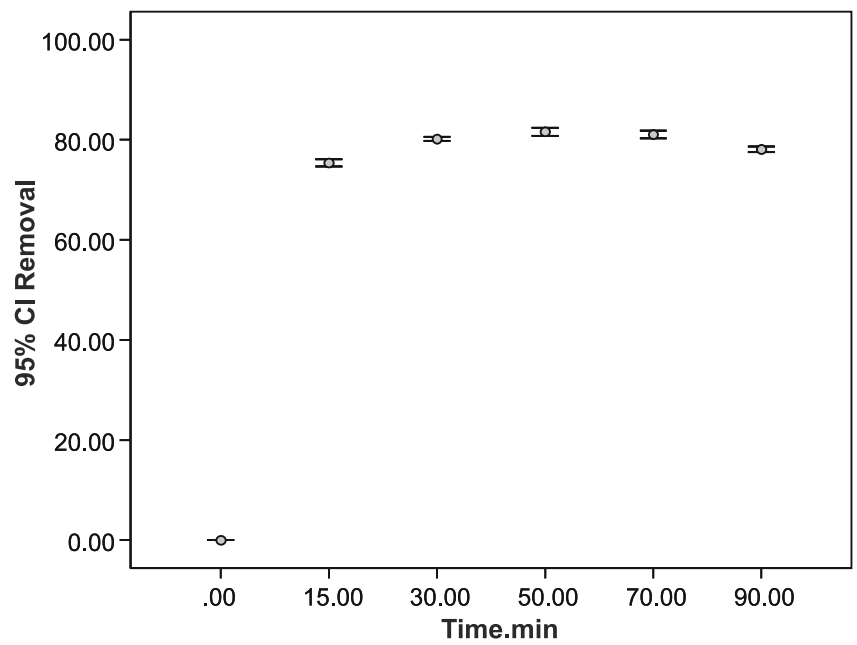

Figure 1b. Biosorption of $100 \mathrm{ml} \mathrm{Pb}^{2+}$ solution, 100 and $25 \mathrm{mg} / \mathrm{L}$, by Gracilaria corticata $200 \mathrm{rpm}$ shaking rate in different times

\begin{tabular}{|l|c|c|c|c|c|}
\hline & Sum of squares & $\mathrm{df}$ & Mean square & $\mathrm{F}$ & Sig. \\
\hline Between groups & 30995.665 & 5 & 6199.133 & \multirow{2}{*}{17070.683} & 0.000 \\
Whiten groups & 8.715 & 24 & 0.363 & & \\
Total & 31004.381 & 29 & & & \\
\hline
\end{tabular}

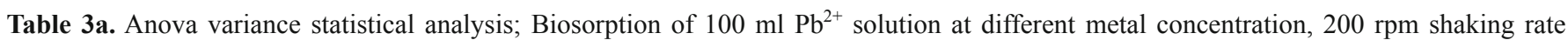
by Sargassum glaucescens during 70 min.

\begin{tabular}{|l|c|c|c|c|c|}
\hline & Sum of squares & df & Mean square & F ig. \\
\hline Between groups & 548.188 & 4 & 137.047 & 371.262 & 0.000 \\
Whiten groups & 7.383 & 20 & 0.369 & & \\
Total & 555.571 & 24 & & & \\
\hline
\end{tabular}

Table 3b. Anova variance statistical analysis; Biosorption of $100 \mathrm{ml} \mathrm{Pb}{ }^{2+}$ solution at different metal concentration, $200 \mathrm{rpm}$ shaking rate by $G$. corticata during $50 \mathrm{~min}$. 
Table 4a. Anova variance statistical analysis; Biosorption of $100 \mathrm{ml} \mathrm{Pb}^{2+}$ solution at different initial $\mathrm{pH}, 200 \mathrm{rpm}$ shaking rate $200 \mathrm{ppm}$ $\mathrm{Pb}^{2+}$ solution by Sargassum glaucescens in 70 min.

\begin{tabular}{|l|c|c|c|c|c|}
\hline & Sum of squares & df & Mean square & F & Sig. \\
\hline Between groups & 548.188 & 4 & 137.047 & 371.262 & 0.000 \\
Whiten groups & 7.383 & 20 & 0.369 & \\
Total & 555.571 & 24 & & \\
\hline
\end{tabular}

Table 4b. Anova variance statistical analysis; Biosorption of $100 \mathrm{ml} \mathrm{Pb}^{2+}$ solution at different initial $\mathrm{pH}, 200 \mathrm{rpm}$ shaking rate $15 \mathrm{ppm}$ $\mathrm{Pb}^{2+}$ solution by $G$. corticata in $50 \mathrm{~min}$.

\begin{tabular}{|l|c|c|c|c|c|}
\hline & Sum of squares & df & Mean square & F & Sig. \\
\hline Between groups & 2189.063 & 4 & 547.266 & \multirow{2}{*}{1917.204} & 0.000 \\
Whiten groups & 5.709 & 20 & 0.285 & \\
Total & 2194.772 & 24 & & \\
\hline
\end{tabular}

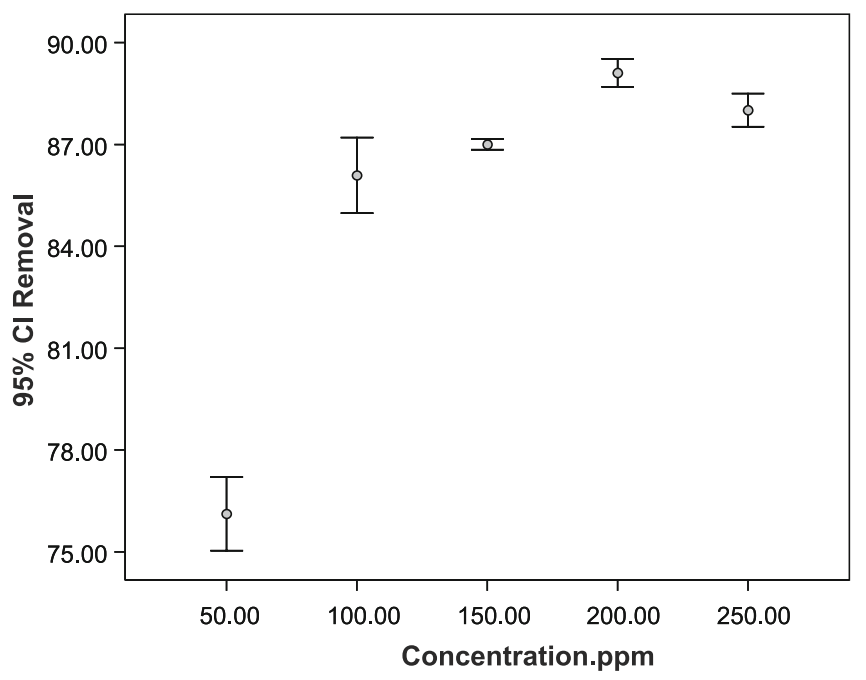

Figure 2a. Biosorption of $100 \mathrm{ml} \mathrm{Pb}^{2+}$ solution at different metal concentration, $200 \mathrm{rpm}$ shaking rate by Sargassum glaucescens during $70 \mathrm{~min}$

biosorption of $180 \mathrm{mg} / \mathrm{L} \mathrm{Cu}$ (II) solution in a packed column in the range of $80 \%{ }^{22}$.

\section{Effect of pH on adsorption}

The initial $\mathrm{pH}$ of the metal solution is an important parameter affecting adsorption of metal ions $\mathrm{s}^{23}$. The effect of solution $\mathrm{pH}$ on biosorption was studied at room temperature by varying the $\mathrm{pH}$. Results have been shown in figure $3 \mathrm{a}$ and figure $4 \mathrm{~b}$.

When $S$. glaucescens has been used for $\mathrm{pb}^{2+}$ ion biosorption, significant difference, was not observed in the removal percent, by the changes of $\mathrm{pH}$ from 3 to 13. But, the changes of $\mathrm{pH}$ values from acidic to basic conditions decreased the $\mathrm{pb}^{2+}$ removal by using G. corticata as a biosorbent. At least, for both S. glaucescens and G. corticata, maximum removal of $\mathrm{pH}$ occurred in acidic conditions: $\mathrm{pH} 3$ and $\mathrm{pH} 5$ in the range of 95.6 and $86.4 \%$, respectively. Actually, in basic conditions, the groups of biosorbent could uptake fewer $\mathrm{pb}^{2+}$ ions.

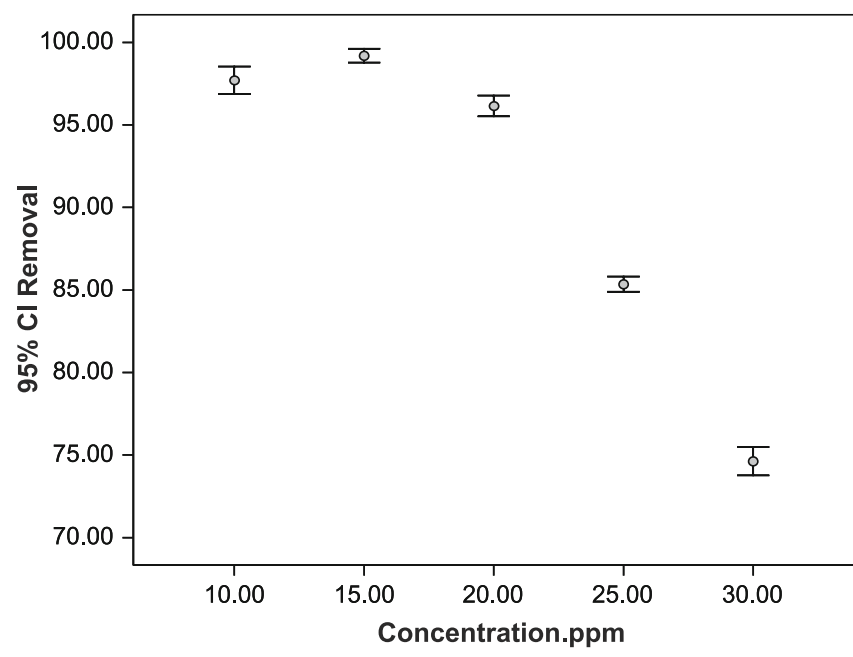

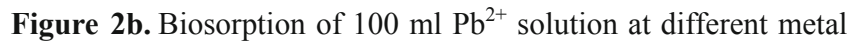
concentration, $200 \mathrm{rpm}$ shaking rate by Gracilaria corticata during $50 \mathrm{~min}$

Kadirvelu et al, obtained maximum removal of heavy metals pb (II), Cd (II), Ni (II) and Cu (II), by increasing $\mathrm{pH}$ from 2 to 6 and using activated carbon prepared from an agricultural soil waste ${ }^{24}$ Gupta et al, obtained maximum biosorption of chromium (VI) by green algae Spirogyra species in optimum $\mathrm{pH}$ of $2^{14}$.

\section{Adsorption isotherm}

Adsorption isotherms are important for the description of how an adsorbate will interact with an adsorbent and are critical in the use of adsorbents. Equilibrium studies on adsorption isotherms are characterized by certain constants whose values express the surface properties and affinity of the adsorbent. Equilibrium between the adsorbent and the adsorbate is described by adsorption isotherms, usually the ratio between the quantity adsorbed and that remaining in the solution at a fixed temperature $\left(23 \pm 2^{\circ} \mathrm{C}\right)$, at equilibrium. To study the adsorption isotherm, two models were analyzed.

\begin{tabular}{|l|c|c|c|c|c|}
\hline & Sum of squares & df & Mean square & F & Sig. \\
\hline Between groups & 3527.586 & 4 & 881.896 & \multirow{2}{*}{5931.108} & 0.000 \\
Whiten groups & 2.974 & 20 & 0.149 & 24 & \\
Total & 3530.560 & & & \\
\hline
\end{tabular}

Table 5a. Kinetic modeling biosorption by Sargassum glaucescens, sencond-order kinetic model

\begin{tabular}{|l|c|c|c|c|c|}
\hline & Sum of squares & df & Mean square & S & \\
\hline Between groups & 701.158 & 4 & 175.290 & \\
Whiten groups & 8.245 & 20 & 0.412 & 425.212 & 0.000 \\
Total & 709.403 & 24 & & \\
\hline
\end{tabular}

Table 5b. Kinetic modeling biosorption by Gracilaria corticata, second-order kinetic model 


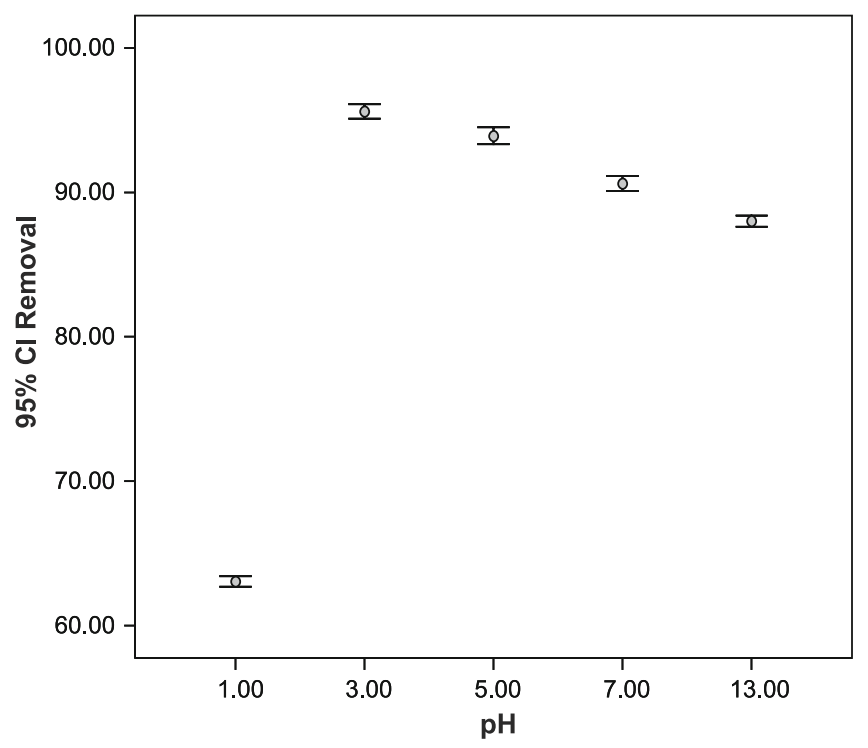

Figure 3a. Biosorption of $100 \mathrm{ml} \mathrm{Pb}^{2+}$ solution at different initial $\mathrm{pH}, 200 \mathrm{rpm}$ shaking rate $200 \mathrm{ppm} \mathrm{Pb} 2+$ solution by Sargassum glaucescens in $70 \mathrm{~min}$.

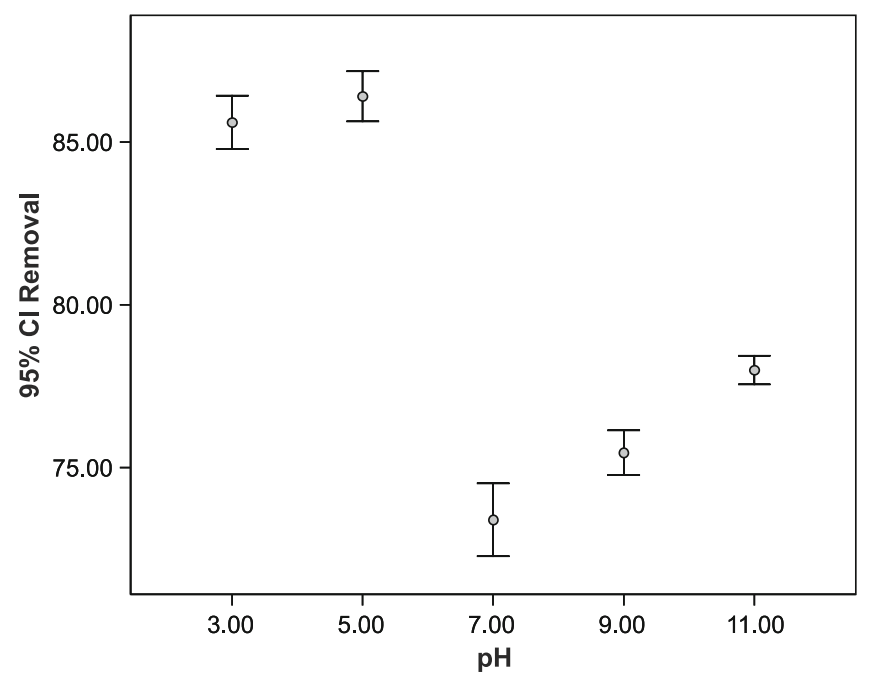

Figure 3b. Biosorption of $100 \mathrm{ml} \mathrm{Pb}^{2+}$ solution at different initial

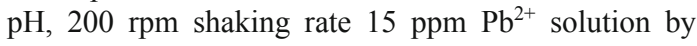
Gracilaria corticata in $50 \mathrm{~min}$.

\section{Langmuir and Freundlich isotherms}

The Langmuir adsorption isotherm is the most widely applied adsorption isotherm. A basic assumption of the Langmuir theory is that adsorption takes place at specific homogeneous sites within the adsorbent. The applicability of the empirical Freundlich isotherm was also analyzed based on the sorption on a heterogeneous surface, using the same set of experimental data of dried brown algae and its activated carbon. The isotherm experimental results showed that the data could be well modeled according to the Langmuir and Freundlich adsorption isotherm (Figure's $4 a$ and $4 b$ ).

The Langmuir constant $\left(\mathrm{q}_{\max }\right)$ is dependent on experimental conditions such as solution $\mathrm{pH}$. Another importance in evaluating the sorbent performance is the initial gradient of the adsorption isotherm, since it indicates the sorbent affinity at low metal concentrations. In the Langmuir equation, this initial gradient corresponds to the affinity constant. As we can see from Table 1 the data could be well modeled according to either the Langmuir or Freundlich adsorption isotherm. In previous investigations, a similar method using the
Freundlich, Sargassum

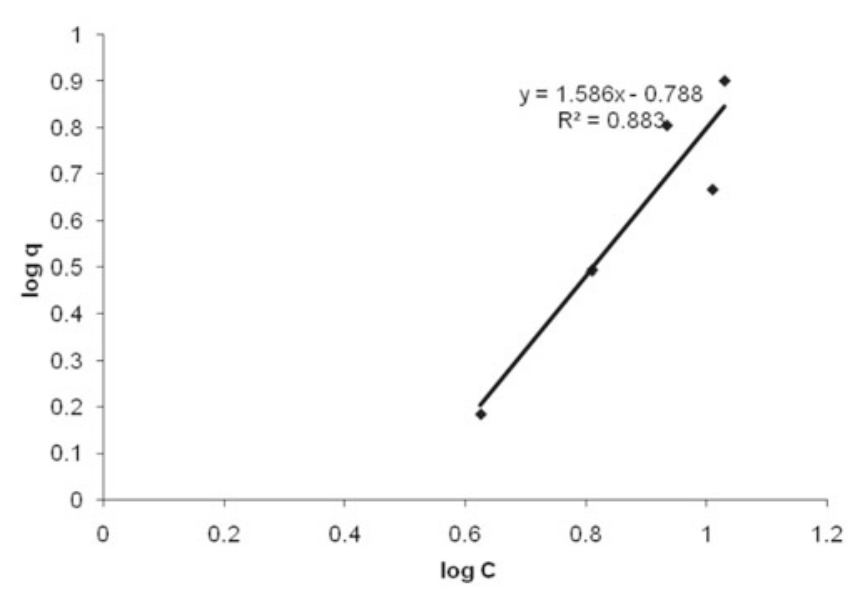

Figure 4a. The isotherm models biosorption by Sargassum glaucescens, the Frundlich model

Langmuir, Gracilaria

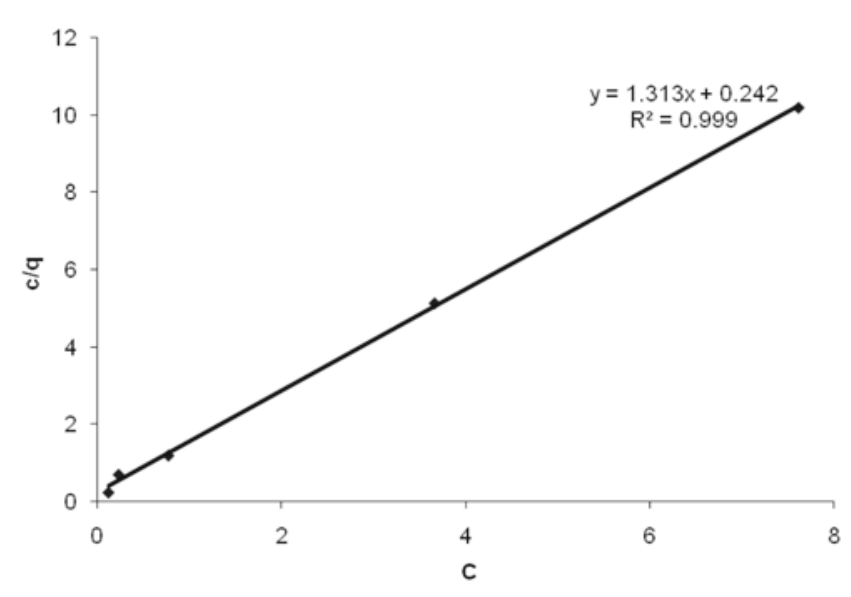

Figure $\mathbf{4 b}$. The isotherm models biosorption by Gracilaria, the Langmuir model

marine algae Gracilaria for the biosorption of $\mathrm{Ni}$ (II) has been reported".

\section{Kinetic modeling}

The second and first-order rate constant $\left(\mathrm{k}_{1, \mathrm{ads}}\right)$ and $\mathrm{q}_{\mathrm{e}}$ determined from the model indicated that this model failed to estimate qe since the experimental values of qe differed from those estimated in Table 2 and figure's $5 \mathrm{a}$ and $5 \mathrm{~b}$.

Subsequently, the rate of uptake of $\mathrm{Pb}^{2+}$ onto the biomass increased quickly to 70 and $90 \mathrm{~min}$, and no further adsorption was observed beyond this period. The $\mathrm{Pb}^{2+}$ uptake by the biosorbents was best described by the pseudo second-order rate model. The pseudo second-order model is based on the supposition that adsorption follows a second order, which means the rate of occupation of adsorption sites, is proportional to the squares of the number of unoccupied sites ${ }^{19}$. In previous literature for the evaluation of the $\mathrm{AC}$ prepared from the algae Gracilaria for the adsorption of $\mathrm{Cu}$ (II) the adsorption follows the second-order rate expression?

\section{Adsorption equilibrium}

The isotherm experimental results showed that the data could be well modeled according to the Langmuir adsorption isotherms (figure's $4 a$ and $4 b$ ). The Langmuir 
Table 2. The parameters obtained for the first and second-order kinetic model by two biosorbent

\begin{tabular}{|l|c|c|c|c|c|c|c|}
\hline Algae & $\mathrm{C}_{0}, \mathrm{pb}^{2+}$ & $\mathrm{K}_{1}$ & $\mathrm{q}_{\mathrm{e}}$ (first-order) & $\mathrm{R}^{2}$ & $\mathrm{~K}_{2}$ & $\mathrm{q}_{\mathrm{e}}$ (second-order) & $\mathrm{R}^{2}$ \\
\hline S. glaucescens & 100 & 0.00092 & 1.64 & 0.692 & 0.003 & 93.5 & 0.999 \\
\hline G. corticata & 25 & 0.00046 & 1.40 & 0.1345 & 0.183 & 19.8 & 0.998 \\
\hline
\end{tabular}

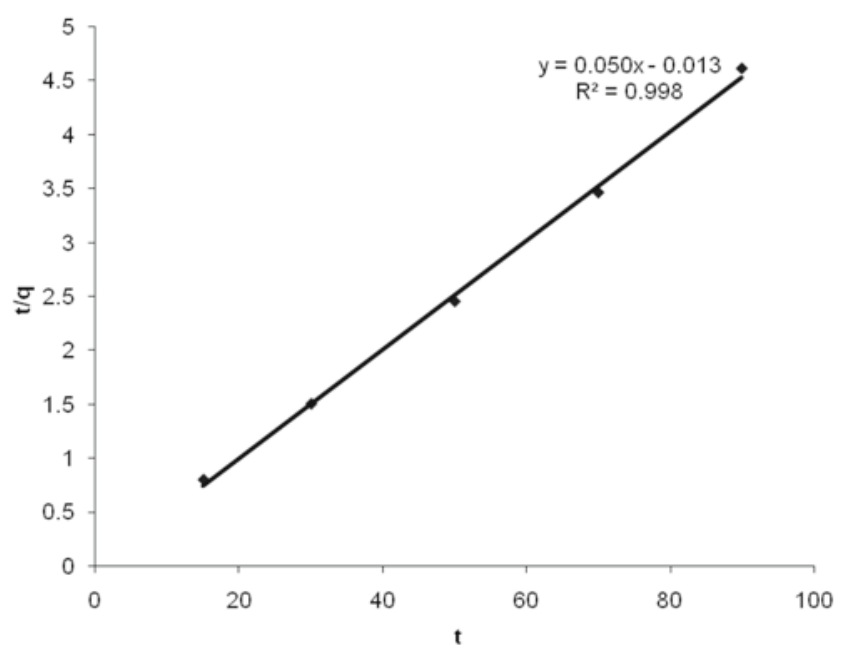

Figure 5a. Kinetic modeling biosorption by Sargassum glaucescens, sencond-order kinetic model

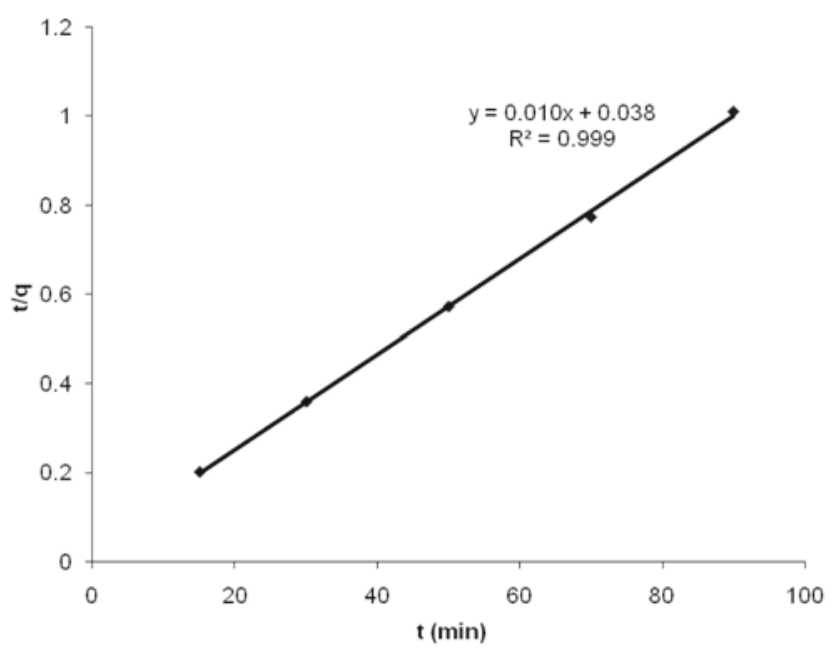

Figure 5b. Kinetic modeling biosorption by Gracilaria corticata, second-order kinetic model

constant $\left(\mathrm{q}_{\max }\right)$ is dependent on experimental conditions such as solution $\mathrm{pH}$. Another important factor in evaluating the sorbent performance is the initial gradient of the adsorption isotherm, since it indicates the sorbent affinity at low metal concentrations. In the Langmuir equation, this initial gradient corresponds to the affinity constant. The Freundlich and Langmuir isotherm constants were obtained and are presented in Table 1.

\section{CONCLUSION}

In this study, adsorption of $\mathrm{pb}^{2+}$ on two Marine algae G. corticata (red algae) and Sargassum glaucescens (brown algae) has been studied. These treated biomass could be used as a low cost adsorbent for the removal of $\mathrm{pb}^{2+}$ from aqueous solution. The adsorption of metal ions is dependent on the amount of concentration of $\mathrm{pb}^{2+}$, $\mathrm{pH}$ and retention time. The adsorption rate would be increased by increasing time to 70 and $50 \mathrm{~min}$ by $S$. glaucescens and $G$. corticata, respectively. The results showed that $S$. glaucescens is more effective for the removal of $\mathrm{pb}^{2+}$, in optimum conditions of the process in the range of $95.6 \%$. Gracilaria has adsorbed $\mathrm{pb}^{2+}$, in optimum conditions in the range of $86.4 \%$. The equilibrium adsorption data by $S$. glaucescens and $G$. corticata are correlated to the Freundlich and Langmuir isotherm equation, respectively, and can be described by the second-order kinetic models.

\section{LITERATURE CITED}

1. Alloway, B.Y. \& Ayres, D.C. (1997). Chemical of Environmental pollution. $2^{\text {nd }}$ Ed., Chapman Hall, pp. 117-213.

2. Volesky, B. \& Holan, Z.R. (1995). Biosorption of heavy metals. Biotechnol. Progress, 11, 235-250. DOI: 10.2225/vol10.

3. Vijayaraghavan, K., Padmesh, T.V.N., Palanivelu, K. \& Velan, M. (2006). Biosorption of nickel ions onto Sargassum wighiti: Application of two-parameter and three-parameter isotherm models. J. of Hazard. Materials, 133, 304-308. DOI: pjbs.2007.3919.3922.

4. Kortenkamp, A., Casadevall, M., Faux, S.P., Jenner, A., Shayer, R.O.J., Woodbridge, N., \& O’Brien, P.A. (1996). Role for molecular oxygen in the formation of DNA damage during the reduction of the carcinogen chromium (VI) by glutathione. Biochem. and Biophy., 29, 199-208. DOI: abs/10.1021/ja974240z.

5. Guibal, C., Roulph, C., \& Cloirec, P.L. (1992). Uranium biosorption by a filamentous fungus Mucor miehei: $\mathrm{pH}$ effect on mechanisms and performances of uptake. Water Res., 26, 1139-1145.

6. Fourest, E. \& Roux, J.C. (1992). Heavy metal biosorption by fungal mycelia by-products: mechanisms and influence of pH. Appl. Microbiol. Biotechnol., 37, 399-403. DOI: abs/10.1080/09593332508618378.

7. Figueira, M., Volesky, B., Ciminelli, V.T.S. \& Roddick, F.A. (2000). Biosorption of metals in brown seaweed biomass. Water Res., 34, 196-204. DOI: org/10.1016/S0043-1354(99)00120-7.

8. Davis, T.A., Volesky, B. \& Mucci, A. (2003). A review of the biochemistry of heavy metal biosorption by brown algae. Water Res., 37, 4311-4330. DOI: 10.1029/2010GL044771.

9. Esmaeili, A. \& Ghasemi, S. (2009). Evaluation of the Activated Carbon Prepared of Algae Marine Gracilaria for the Biosorption of Ni (II) from Aqueous Solutions. World Appl. Sci. J., 6 (4), 515-518. DOI: 10.1007/s11270-010-0635-2.

10. Esmaeili, A., Ghasemi, S. \& Sohrabipour, S. (2010a). Biosorption of copper from wastewater by activated carbon preparation from alga Sargassum sp. J. Nat. Prod. Res., 24(4), 341-348. DOI: org/10.1016/j.arabjc.2012.01.008.

11. Esmaeili, A., Ghasemi, S. \& Rustaiyan, A. (2010b). Removal of hexavalent chromium using activated carbons derived from marine algae gracilaria and sargassum sp. J. of Marine Sci. and Technol., 18(4), 587-592. DOI: org/10.1016/j. arabjc.2012.01.008.

12. Matheickla, J.T., Yu, Q. (1997). Cu (II) binding by E. radiate biomaterial. J. Environ. Technol., 18, 25-34. DOI: abs/10.1080/09593332508618469.

13. Ghorbani, F. \& Younesi, H. (2008). Biosorption of Cd (II) ions by Saccharomyces cerevisiane biomass from aqueous solutions. Water and Wastewater, 68, 33-39.

14. Gupta, K.V. \& Shirivastava, A.K. (2001). Biosorption of $\mathrm{Cr}$ (VI) from aqueous solution by green algae Spirogyra species. Water Res., 35, 4077-4085. DOI: 10.1016/S0043-1354(01)00138-5.

15. Freundlich, H. (1906). Uber die adsorption in losungen, Zeitschrift fur. Physikalische Chemie, 57, 385-470. DOI: abs/10. 1080/02772248.2011.636043. 
16. Padmesh, T.V.N., Vijayaraghavan, K., Sekaran, G. \& Velan, M. (2006). Application of Azolla rongpong on biosorption of acid red 88, acid green 3 , acid orange 7 and acid blue 15 from synthetic solutions. Chem. Eng. J., 122, 55-63. DOI: 10.1016/j.cej.2006.05.013.

17. Kundu, S. \& Gupta, A. (2006). Arsenic adsorption onto iron oxide-coated cementers and their optimization. Chem. Eng. J., 122, 93-106. DOI: 10.1016/j.jhazmat.2007.01.006.

18. Golder, A.K., Samanta, A. \& Ray, S. (2006). Anionic reactive dye removal from aqueous solution using a new adsorbent-sludge generated in removal of heavy metal by electro coagulation" Chem. Eng. J., 122, 107-115. DOI: 10.1016/j. jhazmat.2009.09.155.

19. Ho, Y.S. \& McKay, G. (1999). Pseudo-second order model for sorption. Process Biochem. 34, 451-65. DOI: 10.1016/j. jhazmat.2005.12.043.

20. Doenmez, G. \& Aksu, Z. (2002). Removal of chromium (VI) from saline wastewaters by Dunaliella species. Process Biochem., 38, 751-762. DOI: 10.3906/biy-0810-3.

21. Ag, Y. \& Aktay, Y. (2002). Kinetics studies of $\mathrm{Cr}(\mathrm{VI})$ and $\mathrm{Cu}$ (II) ions by chitin, chitosan and Rhizopus arrhizus. Biochem. Eng., 12, 143-53. DOI: 10.1016/j.hydromet. 2005.07.004.

22. Esmaeili, A., Ghasemi, S. \& Rustaiyan, A. (2008). Evaluation of the activated carbon prepared from the algae Gracilaria for the biosorption of $\mathrm{Cu}$ (II) from aqueous solutions. J. of Marine Env. Eng., 9, 65-73. DOI: 10.4236/msa.2011.22010.

23. Matheickla, J.T. \& Yu, Q. (1996). Biosorption of Lead from aqueous solution by marine alga Ecklonia radiate. Water Sci. Tech., 34, 1-7. DOI: pjbs.2002.332.334 .

24. Kadirvelu, K., Thamaraiselvi, K., \& Namasivayam, C. (2001). Removal of heavy metals from industrial wastewater by adsorption onto activated carbon prepared from an agricultural solid waste. Bioresource Technol., 76, 63-65. DOI: 10.1016/ S0960-8524(00)00072.

25. Esmaeili, A., Beirami, P. \& Ghasemi, S. (2011). Evaluation of the marine algae Gracilaria and its activated carbon for the adsorption of $\mathrm{Ni}(\mathrm{II})$ from wastewater. E-Journal of Chem., 2011, 8(4): 1512-1521. DOI: 10.1155/2011/137484. 